A Note About Energy Savings and Substation KVA

Load Reduction Resulting From Power Factor Correction Capacitors

Proton Center Example

\title{
Abstract
}

A discussion of the power factors of SCR controlled power supplies is given. Power factors are generally poor ( $\mathrm{PF}=0.6)$. Power factor correction capacitors can be installed to correct this. The Proton Center experimental area is given as an example.

The P-Center case is rather typical for experimental area loads. Power supply loading changes often. This results in changes in KVAR and P.F. To improve the power factor at a typical 1.5 MVA substation feeding mainly power supplies, to $P F \geq 0.9$, requires the installation of about $1000 \mathrm{KVAC}$ of power factor correction capacitors, with automatic P.F. control. This equipment should be centrally located and would cost about $\$ 60,000$ per substation, installed. Annual savings in losses would be about $\$ 2400$ per bank. Released system capacity and reduction in KVA demand would be about $30 \%$ per installation. It is, at this time, not economical to install such large banks, except in cases where the KVA demand exceeds the installed capacity. It is much more economical to make a partial improvement from $\mathrm{PF}_{1}=0.6$ to $\mathrm{PF}_{2} \sim 0.7$. This can be done by installing about $120 \mathrm{KVAC}$ of power factor correcting capacitors at each $500 \mathrm{KW}$ and $240 \mathrm{KW}$ power supply. These capacitors would be non-automatic and be connected behind the contactor of each power supply. Each installation would cost about $\$ 2,500$, and could save about $\$ 600$ per year in losses. 
I. Power supplies and their power factors

SCR controlled power supplies cause lagging currents at the AC supply line. The value of the power factor of a rectifier unit (power supply) is less than unity for the following reasons:

1. Distortion of the current wave

2. Reactance of the rectifier transformer

3. Transformer exciting current

4. Phase control, which increases the angle of displacement between current and voltage.

Phase control, especially, can result in very low power factors. Assuming that we are not too scientific and say that reasons $1,2,3$ do not affect the power factor, then phase control alone can result in power factors from unity to zero. Our power supplies are equipped with primary $(A C)$ and secondary (DC) taps, so that power factors and line current draw for each specific load can be optimized. A wide range of power supply operating currents, in a short period of time, makes load matching impractical. Pulsedloads are also harder to handle, but pulsing generally reduces real power consumption about 45\% (based on an 8 sec. pulse period and 2 sec. flattop time), compared to D.C. operation. Savings in installed A.C. and cooling capacity are therefore substantial.

Large experimental area magnets, operated at DC current, are good candidates for power factor correction, especially when there is a poor match between required magnet operating parameters 
and available power supply taps. Some types of BM109 magnets operating at $2300 \mathrm{~A}$ and $120 \mathrm{~V}$ DC are very poorly matched to the available power supply taps, and are therefore notorious for poor power factors and large AC line currents. This can be readily seen from the tap combination of a $500 \mathrm{KW}$ power supply, which is listed below.

$$
\begin{gathered}
\frac{500 \mathrm{KW} \text { P.S. Taps }}{5000 \mathrm{~A} \text { at } 100 \mathrm{~V} / 50 \mathrm{~V} / 25 \mathrm{~V}} \\
2500 \mathrm{~A} \text { at } 200 \mathrm{~V} / 100 \mathrm{~V} / 50 \mathrm{~V} \\
1250 \mathrm{~A} \text { at } 400 \mathrm{~V} / 200 \mathrm{~V} / 200 \mathrm{~V}
\end{gathered}
$$

The only tap that can be used is the $2500 \mathrm{~A}, 200 \mathrm{~V}$ combination and a large amount of phase control is needed to obtain the required $120 \mathrm{~V}$ for the $\mathrm{BM} 109$ magnet.

Even when a power supply is full on (100\% rated output voltage) there is already phase control. This phase control is needed for regulation at that point. The power supplies are specified to regulate well at a $10 \%$ low line voltage and the only thing that can be done is to have sufficient phase control to cover a 10\% low line voltage.

The ceiling voltage (maximum output voltage at rated line voltage) of our power supplies is generally 15\% higher than the rated output voltage. Power factors can therefore never be very good.

Typical power factors are about 0.77 at full load and get worse at reduced output voltage as shown in fig. 1, in which I have represented a graph of the power factors of our rectifier power supplies. This graph is applicable for $500 \mathrm{KW}, 240 \mathrm{KW}$ and $55 \mathrm{KW}$ power supplies. 
The power factor P.F. can be calculated from:

$$
\mathrm{PF}=\frac{\mathrm{KW}}{\overline{\mathrm{KVA}}}
$$

which can be written as:

$$
\mathrm{PF}=\frac{\text { load } \mathrm{KW}+\mathrm{PS} \text { internal load current } \mathrm{KW} \text { loss }+ \text { no load } \mathrm{KW} \text { PS loss }}{3 \times \mathrm{PS} \text { line current } \times \frac{480}{\sqrt{3}} \times 10^{-3}}
$$

and estimated to be:

$$
\mathrm{PF}=\frac{1.08 \mathrm{KW} \text { load }+ \text { no load P.S. KW loss }}{0.83 \times \mathrm{P} . \mathrm{S} . \text { line current }}
$$

Roughly estimate:

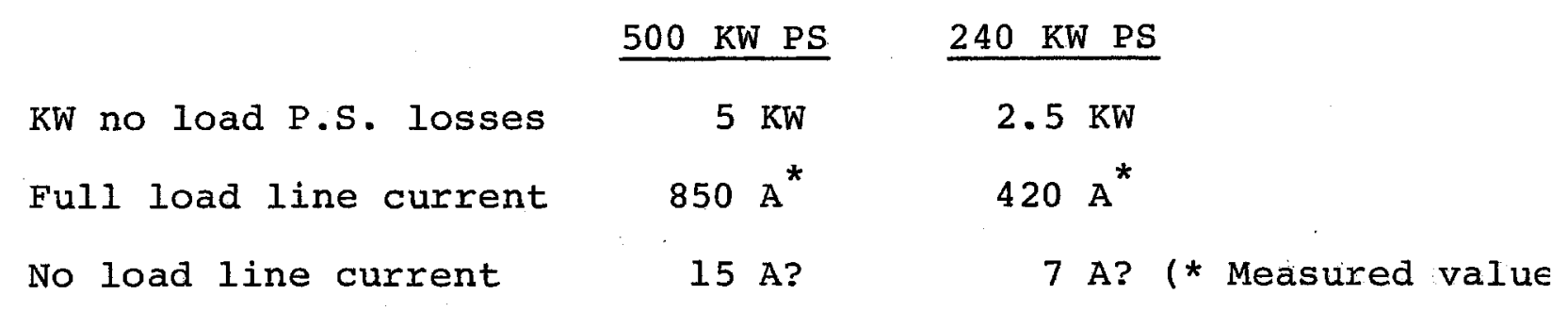

The rated power supply AC line current depends on the selected tap setting. The operating AC line current is linearly proportional to the DC output current.

We can make the following table 1 for various power supply taps.

KVAC $_{\max }$ lists the maximum KVAR the power supply will draw with the worst load/P.S. tap match.

$K=\left(0.83 \frac{I_{L} \text { rated }}{I_{D C} \text { rated }}\right)^{2}$ is a constant for a specific power

supply tap and is used for calculating KVAR. 
TABLE 1

$\underline{P S-500 \mathrm{KW}}$

\begin{tabular}{|c|c|c|c|c|c|}
\hline $\begin{array}{l}\text { P.S. Tap } \\
\text { Setting }\end{array}$ & $\begin{array}{l}\text { Rated P.S. } \\
\text { D.C. Current } \\
\text { From } ~ 30 \% \text { to } \\
100 \% \text { Voltage } \\
\text { Amp. }\end{array}$ & $\begin{array}{l}\text { Worst } \\
\text { Load } \\
\text { Match }\end{array}$ & $\begin{array}{l}\text { Rated P.S. } \\
\text { Line } \\
\text { Current } \\
\text { Amp. }\end{array}$ & $\begin{array}{c}K \\
\times 10^{-4}\end{array}$ & $\begin{array}{l}\text { Approx. } \\
\text { Max. } \\
\text { KVAR } \\
\text { KVAR }_{\text {MAX }} \\
\end{array}$ \\
\hline $5000 \mathrm{~A} / 100 \mathrm{~V}$ & 5000 & $5000 \mathrm{~A} / 50 \mathrm{~V}$ & 850 & 204 & 650 \\
\hline $2500 \mathrm{~A} / 200 \mathrm{~V}$ & 2500 & $1500 \mathrm{~A} / 100 \mathrm{~V}$ & 850 & 796 & 650 \\
\hline $1250 \mathrm{~A} / 400 \mathrm{~V}$ & 1250 & $1250 \mathrm{~A} / 200 \mathrm{~V}$ & 850 & 3185 & 650 \\
\hline $5000 \mathrm{~A} / 50 \mathrm{~V}$ & 5000 & $5000 \mathrm{~A} / 25 \mathrm{~V}$ & 425 & 51 & 325 \\
\hline $2500 \mathrm{~A} / 100 \mathrm{~V}$ & 2500 & $2500 \mathrm{~A} / 50 \mathrm{~V}$ & 425 & 204 & 325 \\
\hline $1250 \mathrm{~A} / 200 \mathrm{~V}$ & 1250 & $1250 \mathrm{~A} / 100 \mathrm{~V}$ & 425 & 796 & 325 \\
\hline $5000 \mathrm{~A} / 25 \mathrm{~V}$ & 5000 & $5000 \mathrm{~A} / 0 \mathrm{~V}$ & 215 & 13 & 180 \\
\hline $2500 \mathrm{~A} / 50 \mathrm{~V}$ & 2500 & $2500 \mathrm{~A} / 0 \mathrm{~V}$ & 215 & 51 & 180 \\
\hline $1250 \mathrm{~A} / 100 \mathrm{~V}$ & 1250 & $1250 \mathrm{~A} / 0 \mathrm{~V}$ & 215 & 204 & 180 \\
\hline
\end{tabular}

$\underline{P S}-240 \mathrm{KW}$

Rated P.S.

D.C. Current

From 30\% to

Setting

$1200 \mathrm{~A} / 200 \mathrm{~V}$

$600 \mathrm{~A} / 400 \mathrm{~V}$

$300 \mathrm{~A} / 800 \mathrm{~V}$
P.S. Tap
100\% Voltage Amp.

1200
600
300

Worst

Load

Match

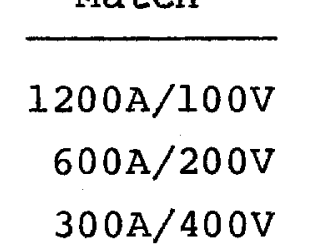

Rated P.S.

Line

Current

Amp.

$$
-
$$

420

420

420

210

210

210

210

$300 \mathrm{~A} / 200 \mathrm{~V}$

300

$1200 \mathrm{~A} / 50 \mathrm{~V}$

$600 \mathrm{~A} / 100 \mathrm{~V}$

$300 \mathrm{~A} / 200 \mathrm{~V}$

1200
600
300

300

$1200 \mathrm{~A} / 0 \mathrm{~V}$
$600 \mathrm{~A} / 0 \mathrm{~V}$
$300 \mathrm{~A} / 0 \mathrm{~V}$

105

105

105

\begin{tabular}{|c|c|}
\hline $\begin{array}{c}K \\
\times 10^{-4}\end{array}$ & $\begin{array}{l}\text { Approx. } \\
\text { Max. } \\
\text { KVAR } \\
\text { KVAR }_{\text {MAX }}\end{array}$ \\
\hline 844 & 320 \\
\hline 3376 & 320 \\
\hline 13502 & 320 \\
\hline
\end{tabular}

$13502 \quad 320$

$211 \quad 160$

$844 \quad 160$

$3376 \quad 160$


TABLE 1 (cont.)

$\underline{P S-55 K W}$

\begin{tabular}{|c|c|c|c|c|c|}
\hline $\begin{array}{l}\text { P.S. Tap } \\
\text { Setting }\end{array}$ & $\begin{array}{l}\text { Rated P.S. } \\
\text { D.C. Current } \\
\text { From } 30 \% \text { to } \\
\text { 100\% Voltage } \\
\text { Amp. }\end{array}$ & $\begin{array}{l}\text { Worst } \\
\text { Load } \\
\text { Match }\end{array}$ & $\begin{array}{l}\text { Rated P.S. } \\
\text { Line } \\
\text { Current } \\
\text { Amp. }\end{array}$ & $\begin{array}{c}K \\
\times 10^{-4}\end{array}$ & $\begin{array}{c}\text { Approx. } \\
\text { Max. } \\
\text { KVAR } \\
\text { KVAR }_{\text {MAX }}\end{array}$ \\
\hline $200 \mathrm{~A} / 275 \mathrm{~V}$ & $200 \mathrm{~A}$ & $200 \mathrm{~A} / 206 \mathrm{~V}$ & 74 & 943 & 41 \\
\hline $100 \mathrm{~A} / 550 \mathrm{~V}$ & $100 \mathrm{~A}$ & $100 \mathrm{~A} / 412 \mathrm{~V}$ & 74 & 3772 & 41 \\
\hline $200 \mathrm{~A} / 206 \mathrm{~V}$ & $200 A$ & $200 \mathrm{~A} / 138 \mathrm{~V}$ & 56 & 540 & 36 \\
\hline $100 \mathrm{~A} / 412 \mathrm{~V}$ & $100 \mathrm{~A}$ & $100 \mathrm{~A} / 275 \mathrm{~V}$ & 56 & 2160 & 36 \\
\hline $200 \mathrm{~A} / 138 \mathrm{~V}$ & $200 A$ & $200 \mathrm{~A} / 69 \mathrm{~V}$ & 37 & 236 & 27 \\
\hline $100 \mathrm{~A} / 275 \mathrm{~V}$ & $100 \mathrm{~A}$ & $100 \mathrm{~A} / 138 \mathrm{~V}$ & 37 & 943 & 27 \\
\hline $200 \mathrm{~A} / 69 \mathrm{~V}$ & $200 \mathrm{~A}$ & $200 \mathrm{~A} / 0 \mathrm{~V}$ & 19 & 62 & 16 \\
\hline $100 \mathrm{~A} / 138 \mathrm{~V}$ & $100 \mathrm{~A}$ & $100 \mathrm{~A} / 0 \mathrm{~V}$ & 19 & 249 & 16 \\
\hline
\end{tabular}


How do we use all this information to calculate the P.F., P.S. line currents, etc.?

\section{Example A}

Take a load running at $2300 \mathrm{~A} / 120 \mathrm{~V}$ which needs a $500 \mathrm{KW}$ P.S. tapped at $2500 \mathrm{~A} / 200 \mathrm{~V}$ (Table 1):

$$
\begin{aligned}
& \text { AC line current }=\frac{D C \text { Current }}{\text { P.S. rated D.C. current }} \times \text { rated line current } \\
& I_{L}=\frac{2300}{2500} \times 850=782 \mathrm{Amp} . \\
& \mathrm{KW}_{\text {Load }}=1.08\left(2300 \times 120 \times 10^{-3}\right)+5=303 \mathrm{KW} \\
& \text { Substation } \mathrm{KVA}=0.83 \times 782=649 \mathrm{kVA}
\end{aligned}
$$$$
\text { P.F. }=\frac{303}{649}=0.466
$$

If we want to use the graph of fig. 1 we can say:

P.S. operating voltage is $\frac{120}{200}=60 \%$ of rated and fig. 1 shows a power factor of 0.47 at that point.

\section{Power Factor Correction Capacitors}

The lagging A.C. line current caused by power supplies, or other loads, can be compensated (reduced) by a leading current caused by installed P.F. correction capacitors. (Fig. 2)

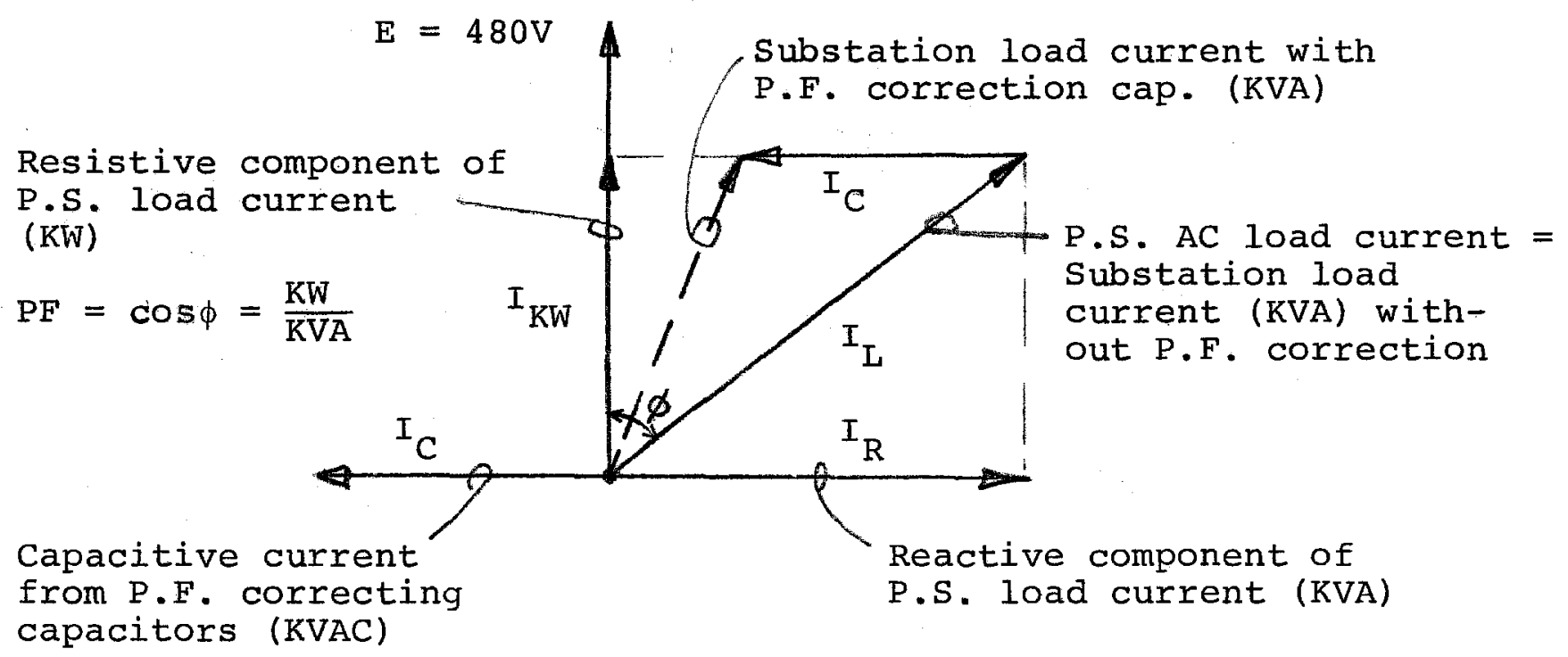


Substantial reduction in substation load current can be obtained as seen from Fig. 2.

The final power factor should be lagging and less than unity. This poses a problem for widely varying loads because experimenters generally operate their magnets over a wide range of current. Some kind of automatic capacitor switching is required. This equipment must switch capacitors on and off in blocks when the D.C. load current changes. Commercially available equipment, such as Westinghouse "Var-Pak" will keep the power factor automatically in balance.

This equipment monitors the P.F. and switches P.F. correction capacitors on and off when the power factor gets out of balance. We could use centralized outdoor equipment, which always stays in place, regardless of equipment changes in the experimental areas. Experiment change over labor cost would then be avoided as far as power factor correction equipment is concerned. This may be the most attractive and least confusing solution*, because experimental areas are in constant turmoil, but substations stay mostly in place. It would also save experimental area floor space, and avoid possible fire code problems for oil-filled units inside buildings. A disadvantage of mounting capacitors at the substations is that the KVA loading of the secondary feeders remains unchanged. Installed power factor correcting capacitors will have the following benefits:

1. Energy savings.

2. Substantial reduction of KVA loading at the substations and feeders, for the same experimental loads. 
$-9-$

3. Better AC line voltage regulation resulting in longer equipment life, especially motors.

4. AC line noise reduction and better AC current form factors.

5. Improved power factor resulting in cheaper cost per KWHR, if there is a penalty clause for low power factor in the utilitycustomer contract.

The following gives us some feel about the size and cost of a typical power factor correction capacitor bank:

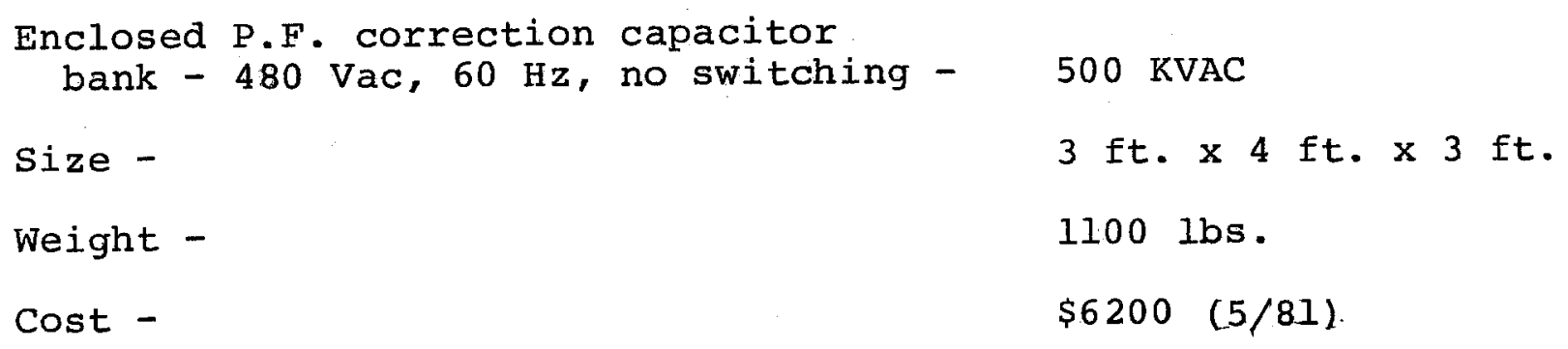

Attached Table 2 permits rapid selection of capacitor $\operatorname{KVAR}(=\mathrm{KVAC})$ required to improve the power factor. 
The required KVAC for a certain amount of power factor improvement can also be calculated as follows:

Let us define circuit values without power factor correction with subnumber 1 and with power factor correction with subnumber 2 . Data from Example A

$$
\begin{aligned}
\mathrm{I}_{\mathrm{L}_{1}} & =782 \mathrm{~A} \\
\text { Load } & =303 \mathrm{KW} \\
\mathrm{KVA}_{1} & =649 \mathrm{KVA} \\
\mathrm{PF}_{I} & =0.47
\end{aligned}
$$

Say we want to increase the power factor to $\mathrm{PF}_{2}=0.9$. The load (KW) does not change.

Thus: $\mathrm{PF}_{2}=\frac{\mathrm{KW}}{\mathrm{KVA}_{2}}=\frac{303}{\mathrm{KVA}_{2}}=0.9$

$$
\mathrm{KVA}_{2}=337 \mathrm{KVA}
$$

In general we can write:

$$
\mathrm{KVA}^{2}=\mathrm{KVAR}^{2}+\mathrm{KW}^{2}
$$

Thus: $649^{2}=\operatorname{KVAR}_{1}^{2}+303^{2}$

$$
\mathrm{KVAR}_{1}=573 \mathrm{KVA}
$$

and with $\mathrm{PF}_{2}=0.9$

$$
\begin{aligned}
& 337^{2}= \operatorname{KVAR}_{2}^{2}+303^{2} \\
& \mathrm{KVAR}_{2}=112 \mathrm{KVA}
\end{aligned}
$$

The required $\mathrm{KVAC}=\mathrm{KVAR}_{1}-\mathrm{KVAR}_{2}$

$$
\begin{aligned}
& \mathrm{KVAC}=573-112 \\
& \mathrm{KVAC}=461 \mathrm{KVAC} \text { for } \mathrm{PF}_{2}=0.9
\end{aligned}
$$

The line current $I_{L_{2}}=\frac{\mathrm{KVA}_{2}}{\mathrm{KVA}_{1}} I_{\mathrm{L}_{1}}$

The ratio of the losses (if this was the only load!) produced by $I_{L_{1}}$ and $I_{L_{2}}$ in the feeders and substation is: 


$$
\begin{aligned}
& \frac{\text { Loss }_{2}}{\operatorname{Loss}_{1}}=\frac{I_{L_{2}} 2}{I_{L_{1}}{ }^{2} R}=\frac{406^{2}}{782^{2}} \\
& \text { Loss }_{2}=0.27 \text { Loss }_{1} \quad(R=\text { feeder }+ \text { substation resistance })
\end{aligned}
$$

Resumé of Example A:

\begin{tabular}{l|c|c} 
P. Factor corr. cap. & 0 & $461 \mathrm{KVAC}$ \\
\hline P. Factor & 0.47 & 0.9 \\
\hline AC line current & $782 \mathrm{~A}$ & $406 \mathrm{~A}$ \\
\hline Load & $303 \mathrm{KW}$ & $303 \mathrm{KW}$ \\
\hline KVA & 649 & 337 \\
\hline $\begin{array}{l}\text { Substation and } \\
\text { feeder loss }\end{array}$ & $\mathrm{L}_{1}$ & $0.27 \mathrm{~L}_{1}$ \\
\hline
\end{tabular}

This example clearly demonstrates that substantial savings in capacity, KVA demand, and losses can be made.

Before we had concluded that the capacitors must be switched on and off in steps because the value of the reactive component of the power supply AC current changes when the DC load current changes. What is the relation between the reactive component of the AC current and the DC operating current? Once we know that, we can select a reasonable "capacitor step" size. Let us see what we can find. 


$$
\begin{aligned}
& \mathrm{KVAR}^{2}=\mathrm{KVA}^{2}-\mathrm{KW}^{2} \\
& \mathrm{KVAR}^{2}=\left(0.83 \mathrm{I}_{\mathrm{L}}\right)^{2}-\mathrm{KW}^{2} \\
& I_{L}=\frac{I_{L} \text { rated }}{I_{D C} \text { rated }} I_{D C}
\end{aligned}
$$

Define: $\quad K=\left(0.83 \frac{I_{L} \text { rated }}{I_{D C} \text { rated }}\right)^{2}$

$K$ is a constant for a selected power supply and tap setting and is listed in table 1.

$$
\mathrm{KVAR}^{2}=\mathrm{KI}_{\mathrm{DC}}^{2}-\mathrm{KW}^{2}
$$

We will neglect the no load power supply loss, thus:

$$
\begin{aligned}
& \mathrm{KVAR}^{2}= \mathrm{KI}_{\mathrm{DC}}^{2}-\left(1.08 \mathrm{I}_{\mathrm{DC}}^{2} \mathrm{R}_{\text {load }} \times 10^{-3}\right)^{2} \\
& \mathrm{KVAR}^{2}= \mathrm{KI}_{\mathrm{DC}}^{2}-1.166\left(\mathrm{I}_{\mathrm{DC}}^{2} \mathrm{R}_{\text {load }} \times 10^{-3}\right)^{2} \\
& \mathrm{I}_{\mathrm{DC}}=\text { Load Amp } \\
& \mathrm{R}_{\text {load }}=\text { Load Ohms }
\end{aligned}
$$

From formula 1) we can plot $K V A R=f\left(I_{D C}\right)$, for example $A$, and find it as shown in fig. 3. Fig. 3 also shows a graph for the best match (load requiring $2500 \mathrm{~A}$ at $200 \mathrm{~V}, 80 \times 10^{-3} \Omega$ ) and the poorest match (load requiring $2500 \mathrm{~A}$ at $100 \mathrm{~V}, 40 \times 10^{-3} \Omega$ ). Normal operation is somewhere in between these extremes, provided a proper tap setting is selected.

Fig. 4 shows the best and worst match KVAR for a $500 \mathrm{~kW}$ P.S. at the $5000 \mathrm{~A} / 100 \mathrm{~V}$ tap. 
Fig. 3 and Fig. 4 are identical. The "worst" case KVAR at the $2500 \mathrm{~A} / 200 \mathrm{~V}$ tap matches the worst case KVAR of the $5000 \mathrm{~A} / 100 \mathrm{~V}$ tap. This could be expected, since in both cases the rated P.S. Iine current will be obtained. For tap combinations yielding only half the line current the worst case KVAR will be half of the value for full line current. From this conclusion we can deduct easily the maximum operating KVAR for all P.S. taps for the "worst case" load match. This is listed in Table 1 under column KVAR MAX .

The experimental area substations feed mostly power supplies. Looking at fig. 3 and fig. 4 and Table 1 we can conclude that it is reasonable to equip each 1.5 MVA substation, feeding mainly power supplies, with $1000 \mathrm{KVAC}$ of power factor correcting capacitors. The step size should be $100 \mathrm{KVAC}$ or smaller. This amount of capacitance will yield power factors of about 0.9 , provided the power supply taps are reasonably matched to the load.

III. P-Center Example

Consider only the big loads BH507, AN520, AN510 and SP508, shown for E-497 on drw. \#ATV 120579. There is a lot of load switching, thus we must be able to switch power factor correcting capacitors on and off automatically. It is already confusing enough. There are three different substations bringing power to P-Center. We can go through the same exercise as in Example $A$ and arrive at the following tables for each power supply. 
Power Supply - BHS 507A (500KW) Fed from Substation PL-2

Note: 2 - 500 KW P.S. in series feed one load BH507

P.S. Tap

\begin{tabular}{l|l|l} 
D.C. load $\left(27 \times 10^{-3} \Omega\right.$ & $100 \mathrm{~V} / 5000 \mathrm{~A}$ & $100 \mathrm{~V} / 5000 \mathrm{~A}$ \\
\hline D.C. load KW & $3600 \mathrm{~A} / 97 \mathrm{~V}$ & $3600 \mathrm{~A} / 97 \mathrm{~V}$ \\
\hline
\end{tabular}

P.F.

A.C. Iine current

Substation KVA

Substation and

Feeder loss

P.F. correction

Capacitor Bank KVAC

Estimated cost of P.F

correcting bank

Estimated cost of

controls, cables

Total est. size

Total est. installed cost (labor \& mat.)

\begin{tabular}{l|l}
0.69 & 0.9 \\
\hline
\end{tabular}

612

469

\begin{tabular}{l|l}
508 & 389 \\
\hline
\end{tabular}

\begin{tabular}{l||l|l}
$\mathrm{L}_{1}$ & $0.59 \mathrm{~L}_{1}$ \\
\hline
\end{tabular}

1)

198

\begin{tabular}{l||l}
\hline 0 & \\
\hline
\end{tabular}

\begin{tabular}{c||c}
- & $\$ 2,500$ \\
\hline- & $20 \mathrm{ft.}{ }^{3}$ \\
\hline 0 & $\$ 10,000$ \\
\hline
\end{tabular}

1) Not considering other loads

2). Includes controls

Power Supply - BHS 507B (500KW) Fed from Substation PL-5

Note: 2 - $500 \mathrm{KW}$ P.S. in series feed one load BH507

\begin{tabular}{|c|c|c|}
\hline P.S. Tap & $100 \mathrm{~V} / 5000 \mathrm{~A}$ & $100 \mathrm{~V} / 5000 \mathrm{~A}$ \\
\hline D.C. load $\left(27 \times 10^{-3} \Omega\right)$ & $3600 \mathrm{~A} / 97 \mathrm{~V}$ & $3600 \mathrm{~A} / 97 \mathrm{~V}$ \\
\hline D.C. load KW & 350 & 350 \\
\hline P.F. & 0.69 & 0.9 \\
\hline A.C. Iine current & 612 & 469 \\
\hline Substation KVA & 508 & 389 \\
\hline $\begin{array}{l}\text { Substation and } \\
\text { feeder loss }\end{array}$ & $\mathrm{L}_{1}$ & $0.59 \mathrm{~L}_{1}$ \\
\hline $\begin{array}{l}\text { P.F. correction } \\
\text { Capacitor Bank KVAC }\end{array}$ & 0 & 198 \\
\hline $\begin{array}{l}\text { Estimated cost of } \\
\text { P.F. correcting bank }\end{array}$ & 0 & $\$ 2,500$ \\
\hline $\begin{array}{l}\text { Estimated cost of } \\
\text { controls, cables } \\
\end{array}$ & 0 & $\$ 2,500$ \\
\hline Total est. size & - & $20 \mathrm{ft} .{ }^{3}$ \\
\hline $\begin{array}{l}\text { Total est. installed } \\
\text { cost (labor \& mat.) }\end{array}$ & 0 & $\$ 10,000$ \\
\hline
\end{tabular}

1)

1) Not considering other loads

2) Includes controls 
Power Supply - ANS 510 (500KW) Fed from Substation PL2B

(This is Example A)

\begin{tabular}{l|l|l} 
P.S. Tap & $200 \mathrm{~V} / 2500 \mathrm{~A}$ & $200 \mathrm{~A} / 2500 \mathrm{~A}$ \\
\hline D.C. Load $\left(52 \times 10^{-3} \Omega\right)$ & $2300 \mathrm{~A} / 120 \mathrm{~V}$ & $2300 \mathrm{~A} / 120 \mathrm{~V}$ \\
\hline D.C. load $\mathrm{KW}$ & 303 & 303
\end{tabular}

D.C. load KW

303
303

P.F.

0.47

0.9

A.C. line current $782 \mathrm{~A}$ $406 \mathrm{~A}$

Substation KVA 649 337

Substation and feeder loss

P.F. correction

Capacitor bank KVAC Estimated cost of P.F. correcting bank Estimated cost of controls, cables

Total est. size

Total est. installed cost (labor \& mat.)

matled

L

$0.27 \mathrm{~L}_{I}$ 1) 461

\begin{tabular}{|c|c|}
\hline 0 & $\$ 6,200$ \\
\hline- & $\$ 4,800$ \\
\hline 0 & $50 \mathrm{ft} .{ }^{3}$ \\
\hline 0 & $\$ 22,000$ \\
\hline
\end{tabular}

1) Not considering other loads

2) Includes controls

Power Supply - ANS 520 (500 KW) Fed from Substation PL-2 Note: This power supply is operated beyond its rated current.

\begin{tabular}{l|l|l} 
P.S. Tap & $2500 \mathrm{~A} / 200 \mathrm{~V}$ & $2500 \mathrm{~A} / 200 \mathrm{~V}$ \\
\hline D.C. load $\left(64 \times 10^{-3} \Omega\right)$ & $2700 \mathrm{~A} / 172 \mathrm{~V}$ & $2700 \mathrm{~A} / 172 \mathrm{~V}$ \\
\hline D.C. load KW & 506 & 506 \\
\hline P.F. & 0.55 & 0.9 \\
\hline A.C. line current, A & 920 & 677 \\
\hline $\begin{array}{l}\text { Substation KVA } \\
\begin{array}{l}\text { Substation and } \\
\text { feeder loss }\end{array}\end{array}$ & 762 & 562 \\
$\begin{array}{l}\text { P.F. Correction } \\
\text { Capacitor bank KVAC }\end{array}$ & 0 & $0.54 \mathrm{~L}_{1}$ \\
\hline $\begin{array}{l}\text { Estimated cost of } \\
\text { P.F. correcting bank }\end{array}$ & 0 & 524 \\
$\begin{array}{l}\text { Estimated cost of } \\
\text { controls }\end{array}$ & 0 & $\$ 6,200$ \\
$\begin{array}{l}\text { Total est. size } \\
\begin{array}{l}\text { Total est. } \\
\text { installed cost }\end{array}\end{array}$ & 0 & $\$ 4,800$ \\
\hline
\end{tabular}

1) Not considering other loads 
Power Supply - SPS 508 (240KW) Fed from Substation PL2B

\begin{tabular}{|c|c|c|}
\hline P.S. Tap & $1200 \mathrm{~A} / 50 \mathrm{~V}$ & $1200 \mathrm{~A} / 50 \mathrm{~V}$ \\
\hline D.C. load $\left(16 \times 10^{-3} \Omega\right)$ & $800 \mathrm{~A} / 16 \mathrm{~V}$ & $800 \mathrm{~A} / 16 \mathrm{~V}$ \\
\hline D.C. load KW & 16 & 16 \\
\hline P.F. & 0.28 & 0.9 \\
\hline A.C. line current, A & 70 & 22 \\
\hline Substation KVA & 58 & 18 \\
\hline $\begin{array}{l}\text { Substation and } \\
\text { feeder loss }\end{array}$ & $\mathrm{L}_{1}$ & $0.01 \mathrm{~L}_{1}$ \\
\hline $\begin{array}{l}\text { P.F. correction } \\
\text { Capacitor Bank KVAC }\end{array}$ & 0 & 48 \\
\hline $\begin{array}{l}\text { Estimated cost of } \\
\text { P.F. correcting bank }\end{array}$ & 0 & $\$ 1,000$ \\
\hline $\begin{array}{l}\text { Estimated cost of } \\
\text { controls/cables }\end{array}$ & 0 & $\$ 2,000$ \\
\hline Total est. size & 0 & $8 \mathrm{ft.}{ }^{3}$ \\
\hline $\begin{array}{l}\text { Total est. } \\
\text { installed cost }\end{array}$ & 0 & $\$ 4,000$ \\
\hline
\end{tabular}

1) Not considering other loads

2) Includes controls 
IV. P-Center - Conclusion

To install automatic power factor correcting capacitors at each individual power supply would roughly cost $\$ 68,000$ including controls. The required total KVAC is about $1000 \mathrm{KVAC}$, which improves the power factor from about $P F=0.5$ (different for various loads) to $\mathrm{PF}=0.9$. Most locations require different size equipment. There are also space and connecting problems.

Power (feeder and transformer) loss savings are hard to estimate. We can, however, conclude that improving the power factor to P.F. = 0.9 will reduce the $480 \mathrm{VAC}$ line currents about $30 \%$. It is reasonable to say that the P-Center load draws a total 480 VAC line current of $2734 \mathrm{~A}$, if we add the individual currents algebraically. However, the currents are phase displaced. Say, therefore, that the total 480 VAC line current to P-Center is 2500 A without P.F. correction and $0.7 \times 2500 \mathrm{~A}=1750 \mathrm{~A}$ with power factor correction. The estimated reduction in secondary feeder current is $\frac{1750}{2500} 100 \%=70 \%$. The estimated reduction in $480 \mathrm{VAC}$ supply losses is $\left(\frac{0.7}{1}\right)^{2} 100 \% \approx 50 \%$. The load losses of a 1.5 MVA substation are $14.5 \mathrm{~kW}$. Use the losses of two 1.5 MVA substations for P-Center. The reduction in substation losses is $2 \times 14.5 \times 0.5 \approx 15 \mathrm{KW}$. Primary feeder loss savings are not as much because other substations use the same feeders. I will only venture to guess that the feeder current gets reduced by 5\%, resulting in $10 \%$ loss savings, or $3 \mathrm{~kW}$ for the P-Center case.

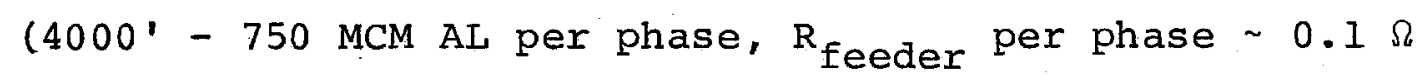
estimate feeder load current $\sim 300 \mathrm{~A}$. Losses without P.F. correction $3 \times 300^{2} \times 0.1 \times 10^{-3}=27 \mathrm{~kW}$. Feeder losses saved with power factor correction $0.1 \times 27 \approx 3 \mathrm{~kW}$. 
Although we have saved about $18 \mathrm{~kW}$ in losses by installing a 1000 KVAC bank, we have added the losses created by the newly installed power factor capacitor bank. I estimate the losses of an automatic 1000 KVAC capacitor bank to be about $3 \mathrm{KW}$. The following summary table can be made for P-Center.

\section{P-Center Conclusion Summary of Estimates}

Power factor correction cap. (Divided among three substations)

Total cost (individually mounted systems)

Loss savings -

New loss from P.F. Cap. banks - $3 \mathrm{KW}$

Net loss savings

Loss savings/year (100\% operation)

Cost/KWHR

Dollars saved/year (100\% operation)

Released system capacity

Reduction in KVA demand
$1000 \mathrm{KVAC}$

$\$ 68,000$

$15 \mathrm{KW}$

130 MWHRS

$\$ 0.04$

$\$ 5,300$

$30 \%$

$30 \%$ 
V. General Conclusion

We can draw some general conclusions from the preceding discussion, for a typical 1.5 MVA experimental area substation for power supplies, equipped with an automatic P.F, correctịng bank, They are listed below.

Substation

Load

Recommended size of P.F. correcting

cap. with automatic P.F. correction, central installation

P.F. w/out capacitors

P.F. with capacitors

Cost - Material - $\$ 40,000$

Labor \&

Misc. $\quad$ \$20,000

Total -

Loss savings:

Feeder

$3 \mathrm{KW}$

Substation $7 \mathrm{KW}$

Losses added:

P.F. Bank (3) KW

Net loss savings

Loss savings/yr. (100\% Operation)

Cost/KWHR

Dollars saved/year (100\% Operation)

Released system capacity

Reduction in KVA demand

Improved sec. voltage regulation
1. 5 MVA

SCR controlled P.S.
$1000 \mathrm{KVAC}$

$\sim 0.6$

$\sim>0.9$

$\$ 60,000$
$7 \mathrm{KW}$

61. MWHRS

$\$ 0.04$

$\$ 2400$

$30 \%$

$30 \%$

$5 \%$ (estimate)

Equipment maintenance and depreciation cost have been ignored in this table. 
Looking at the above numbers it becomes apparent that the installation of a large, central, automatic 1000 KVAC power factor correcting bank is not economical at this time, except in cases where the KVA demand exceeds the installed capacity. Then the question might boil down to a new substation or a capacitor bank. The real savings are in released system capacity of about $30 \%$ and about 5\% better voltage regulation.

It is much more economical to make a partial power factor correction by installing $120 \mathrm{KVAC}$ of power factor correcting capacitors at each $500 \mathrm{KW}$ and $240 \mathrm{KW}$ power supply. These capacitors would be connected at the load side of each power supply contactor. They would thus automatically switch in when the power supply comes on. A time delay of about 3 minutes must be installed before the P.S. can be restarted after a trip. This prevents connecting charged capacitors to the line. The capacitors must have discharge resistors, with a time constant of about one minute. Installing $120 \mathrm{KVAC}$ per power supply would cost $\$ 2500$ each. How much would we save in losses? It will be different for each case, but let us make some realistic assumptions for a typical 1.5 MVA substation as follows: 


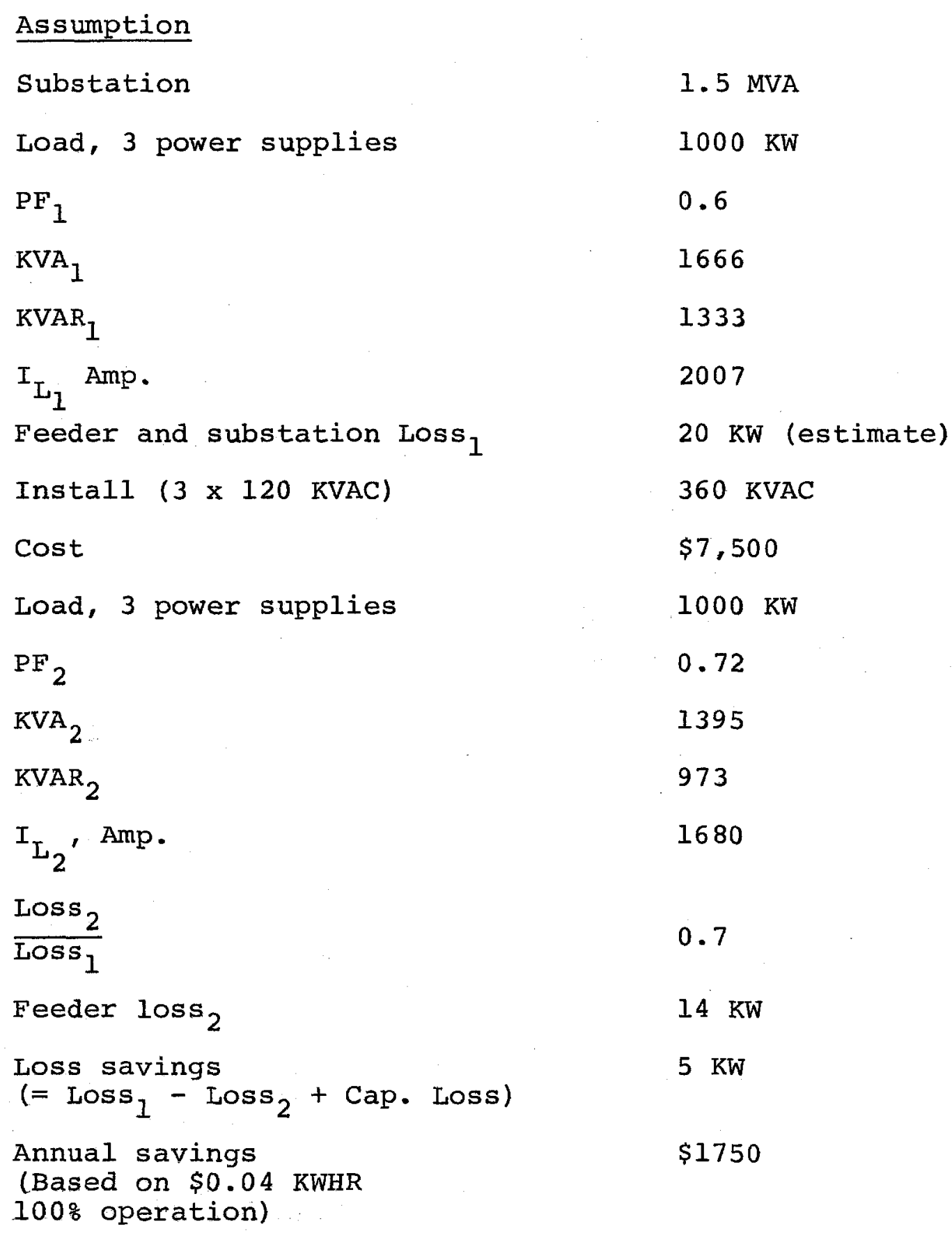

1. 5 MVA

$1000 \mathrm{KW}$

0.6

1666

1333

2007

$20 \mathrm{KW}$ (estimate)

$360 \mathrm{KVAC}$

$\$ 7,500$

$1000 \mathrm{KW}$

0.72

1395

973

1680

0.7

$14 \mathrm{KW}$

$5 \mathrm{KW}$

$\$ 1750$ 
It is obvious that installing $120 \mathrm{KVAC}$ at each power supply makes much more economical sense. It also unloads the secondary feeders and switchboards. A 500 KVAC automatic bank (equipment cost $\$ 19,000)$ could be added centrally in places were it is necessary

In the future we will be running more superconducting loads. This will result (see Table 1 for lowest tap) in a reduction for the KVAR per power supply. The KVAR per substation will, however, remain the same, because we will feed more power supplies from the same substation. The way it looks now, however, most experimental loads will be conventional magnets. 
TM- 1051

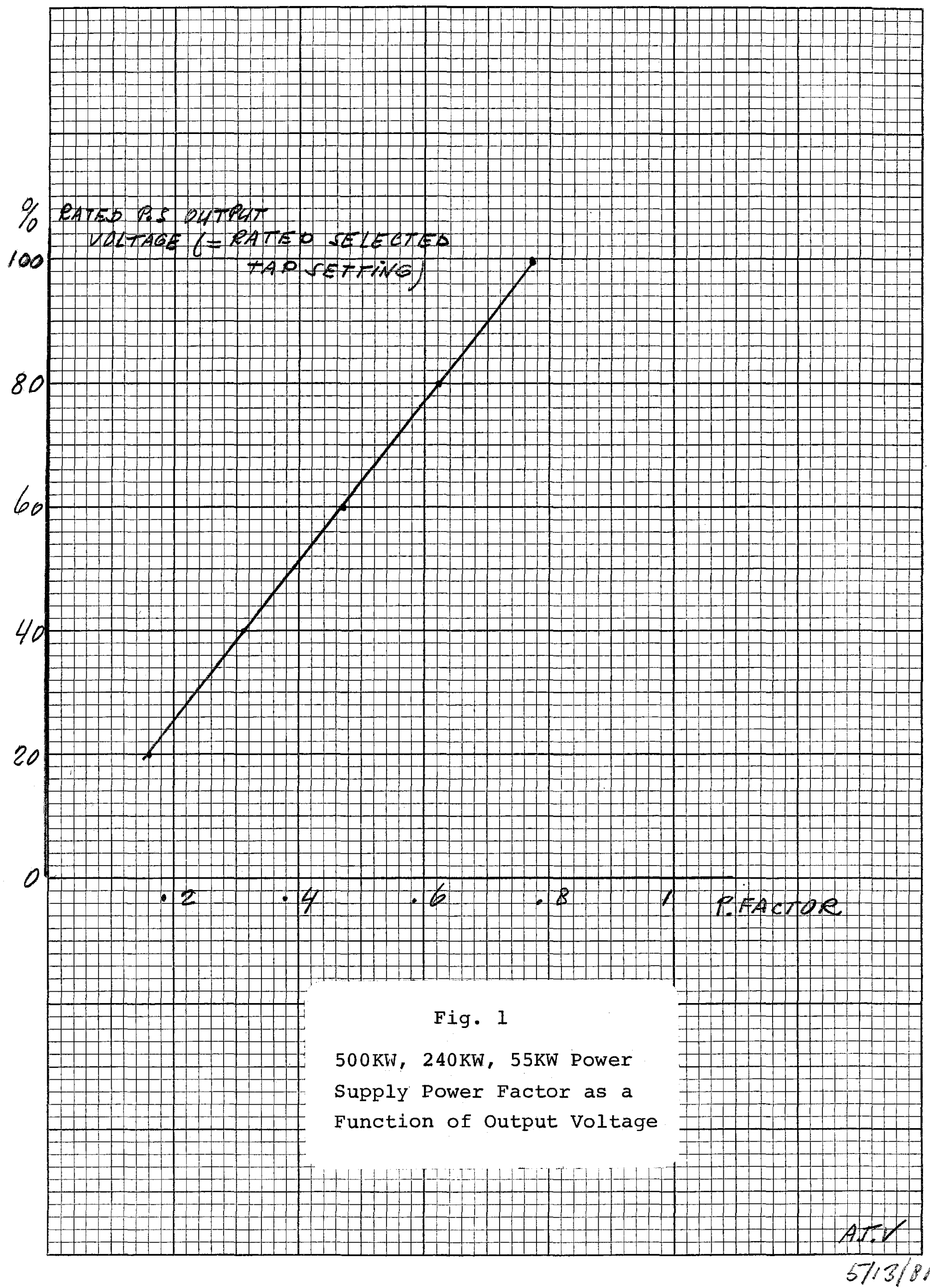




\section{Table for calculating necessary capacitor kvar to improve power factor}

Desired power factor in percentage

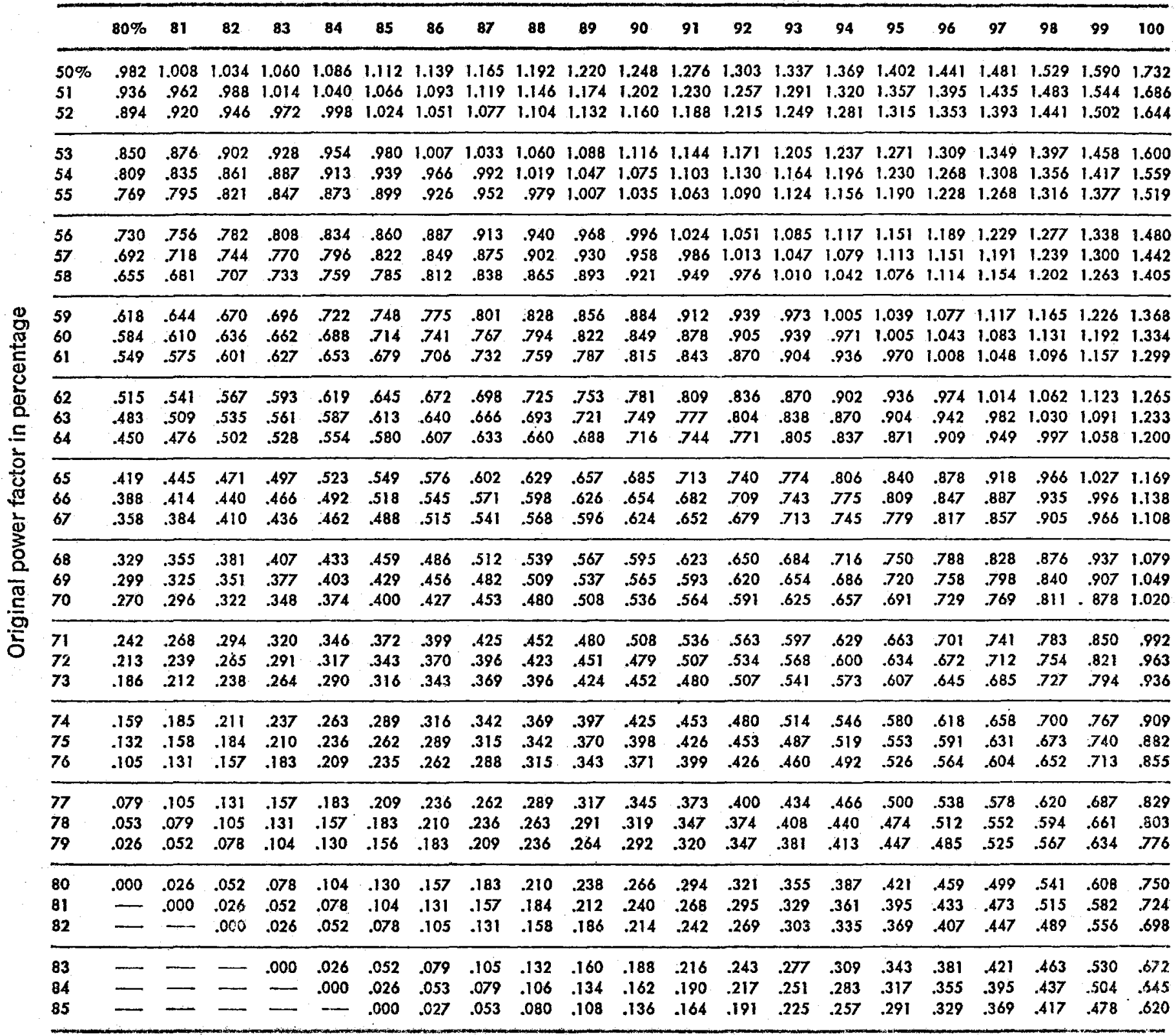

EXAMPLE:

GIVEN:

A circuit supplies a load that has a 100-kilowatt value (either from calculation or from a wattmeter) and operates at a power factor of $68 \%$.

FIND:

What is the required capacitor kvar rating needed to raise the power factor to $96 \%$ ?
ANSWER:

Find the multiplier needed from the Table above by locating $68 \%$ in the vertical column at left and then moving across on that line to the multiplier listed under the top heading of $96 \%$. The multiplier is found to be 0.788 . Then-

$100 \mathrm{kw} \times 0.788=78.8$ kilovars needed 
$T M-1051$

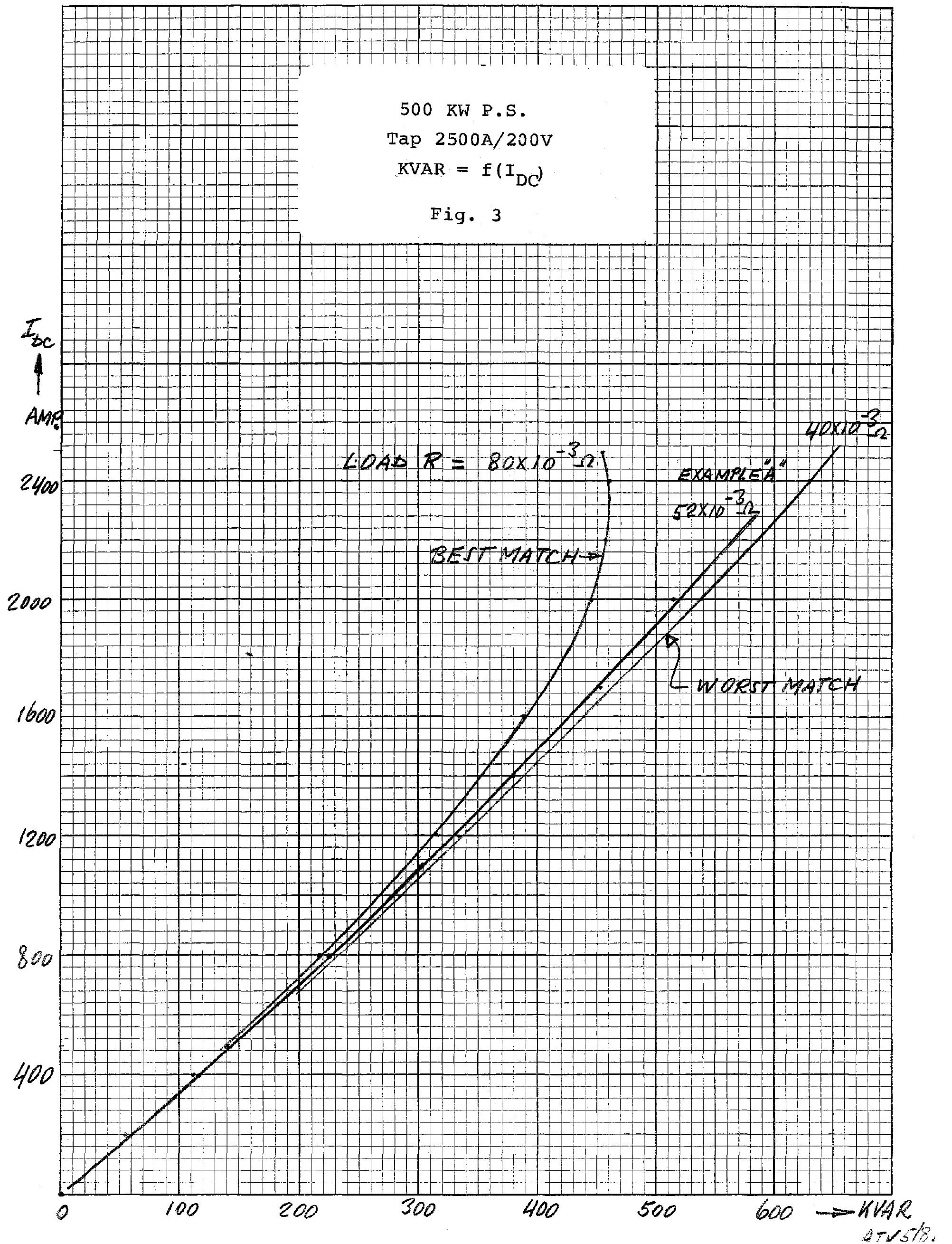


TM-1051

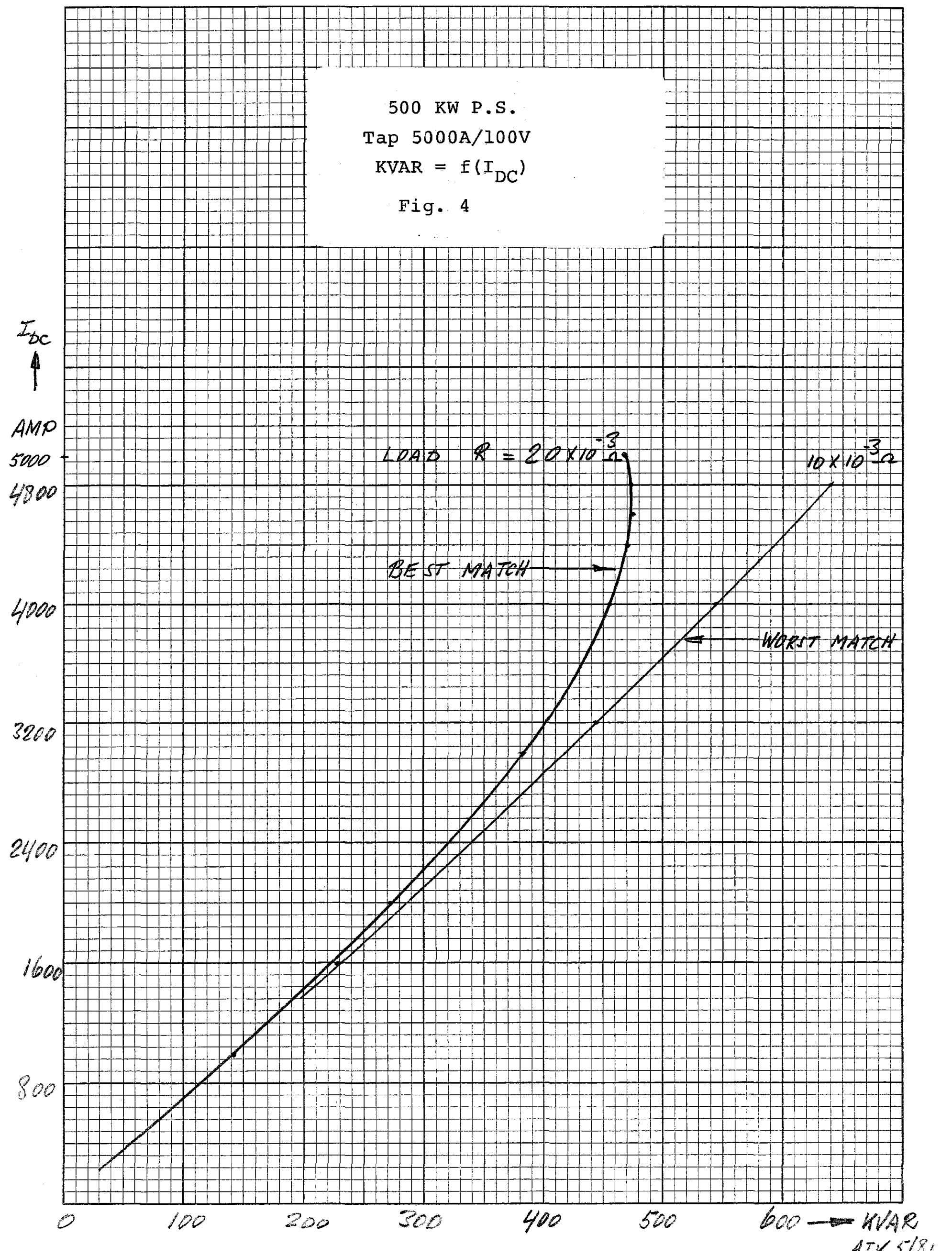




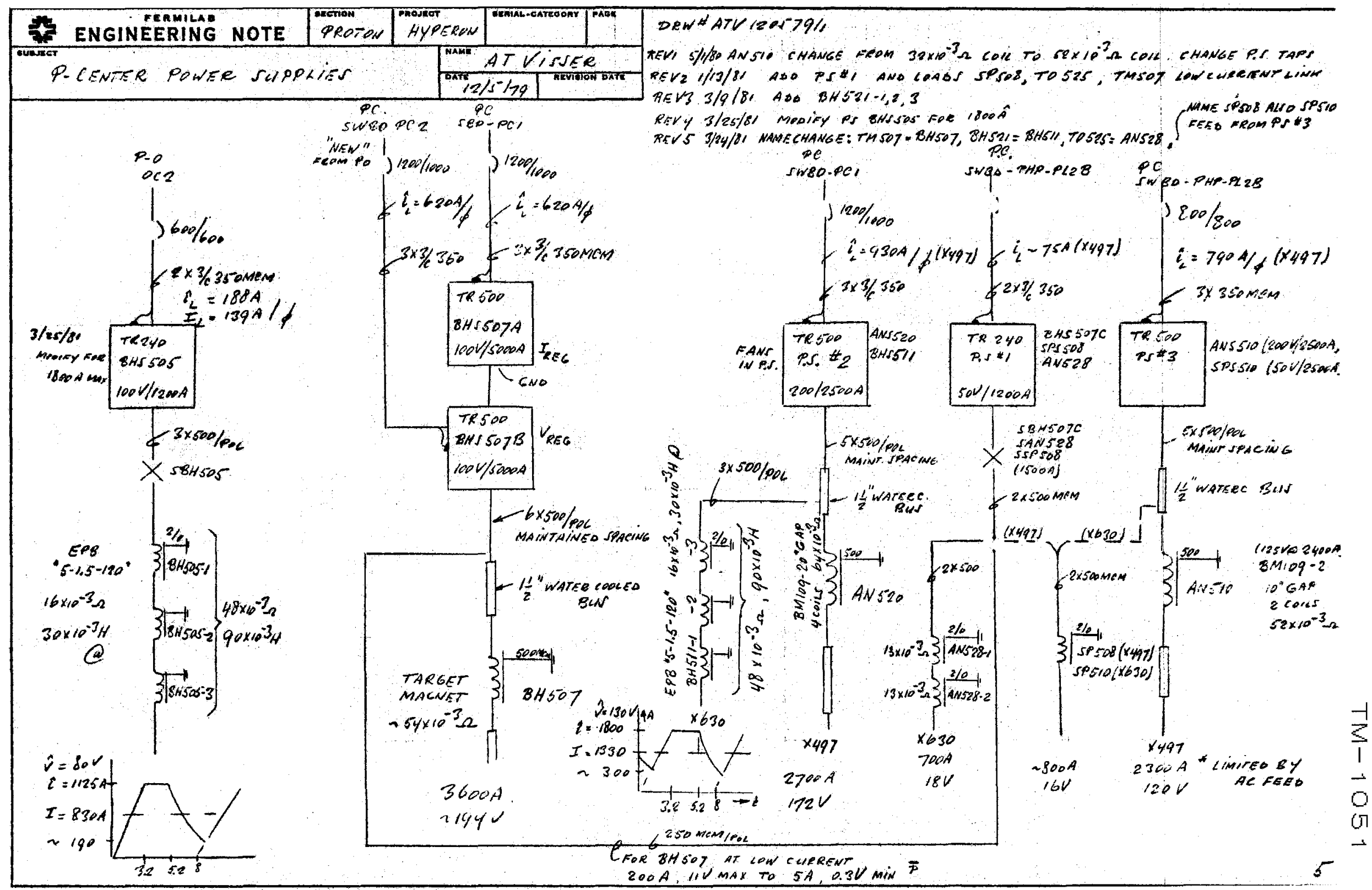

